\title{
Feeding physiology of two bivalves under laboratory and field conditions in response to variable food concentrations
}

\author{
L. A. Velasco ${ }^{1, *}$, J. M. Navarro ${ }^{2}$ \\ ${ }^{1}$ Instituto de Investigaciones Tropicales, Universidad del Magdalena, Carrera 32 No. 22 - 08, Santa Marta, Colombia \\ ${ }^{2}$ Instituto de Biología Marina ‘Dr. Jürgen Winter', Universidad Austral de Chile, Casilla 567, Valdivia, Chile
}

\begin{abstract}
In response to uncertainties about whether laboratory feeding rate measurements of bivalves reflect those occurring in situ, this study compares bivalve feeding rates experimentally determined both in the laboratory and in situ for a mussel (Mytilus chilensis) and a clam (Mulinia edulis), species exposed to a wide range of seston concentrations. Artificially prepared seston was administered in the laboratory using a mixture of Isochrysis galbana and sediment at concentrations ranging from 2 to $200 \mathrm{mg} \mathrm{l}^{-1}$. Field measurements were carried out at Yaldad Bay, southern Chile, during 2 tidal cycles in March and April 1999 with naturally occurring seston ranging from 3 to $665 \mathrm{mg} \mathrm{l}^{-1}$. We found that: (1) Clearance rate (CR) and selection efficiency (SE) were similar in laboratory and in situ conditions, but the rates of filtration (FR), ingestion (IR) and absorption (AR), and absorption efficiency (AE) were significantly higher in the laboratory than in the field. This was attributable to the greater retention efficiency and digestibility of I. galbana compared to the naturally occurring microalgae in the seston, and also to the greater acclimation time of specimens to the laboratory diet. (2) The responses to the changes in seston concentration (TPM) were similar under both conditions and validated previous results; CR decreased exponentially with increasing TPM while the FR, IR and AR increased. At high seston concentrations (200 $\mathrm{mg} \mathrm{l}^{-1}$ in the laboratory and $665 \mathrm{mg} \mathrm{l}^{-1}$ in situ), almost all the feeding rates decreased, showing an impairment of food processing under these conditions. (3) The resuspended sediment in the intertidal zone of Yaldad Bay, especially under the influence of southerly winds and near the lowest tidal level, is an important food source for M. edulis and $M$. chilensis populations, allowing continued growth during the winter season when primary productivity is very low.
\end{abstract}

KEY WORDS: Feeding rates · Mulinia edulis $\cdot$ Mytilus chilensis $\cdot$ Laboratory · Field · Seston · Tidal flats

\section{INTRODUCTION}

A number of studies have been carried out using artificial diets composed of microalgae and sediments to determine feeding adaptations of bivalve filter feeders inhabiting high-turbidity environments (Kiørboe et al. 1980, Kiørboe \& Møhlenberg 1981, Bayne et al. 1987, 1993, Hawkins et al. 1990, Iglesias et al. 1992, Navarro et al. 1996, Riisgård et al. 1996, Bacon et al. 1998). Measurements have also been made in situ, using natural seston (Widdows et al. 1979, Hawkins et al. 1996, 1998, Navarro \& Thompson 1996, Urrutia et al. 1996, Cranford et al. 1998). Results suggest that bivalves respond differently when tested under laboratory and field conditions, as, for example, observed by Urrutia et al. (1996) when working with Cerastoderma edule. These differences may be due to variability in the composition of the food offered or to the different acclimation periods of the specimens to the food. Natural seston contains a greater diversity of components than artificially prepared seston, and its concentration 
and quality may vary over short periods of time (Hawkins et al. 1996, Urrutia et al. 1996, Cranford et al. 1998) impeding acclimation as done in the laboratory. Although it has been argued that feeding rates measured in the laboratory may not reflect those in situ (Riisgård 2001), attempts to intercalibrate both types of studies have not been made.

The infaunal clam Mulinia edulis King 1831 and the epifaunal mussel Mytilus chilensis Hupe 1854 are 2 commercially important filter-feeding bivalves that live on intertidal flats in southern Chile where wide fluctuations in seston concentration are typical (Rojas 1984, Navarro et al. 1993). In spite of the low winter primary productivity, these species demonstrate high growth rates throughout the year (Clasing et al. 1998). Laboratory studies have suggested 'physiological plasticity' which allows the organisms to maintain a positive scope for growth when feeding on resuspended sediment (Velasco \& Navarro 2002, 2003). In order to accept this hypothesis it is necessary to determine whether the feeding responses measured in the laboratory agree with those determined in situ.

The present study measured the principal physiological parameters related to the feeding of these species under a wide spectrum of seston concentrations in order to compare laboratory and field feeding-response measurements, and to validate previous results obtained in the laboratory with Mulinia edulis and Mytilus chilensis. In the laboratory, the bivalves were offered constant concentrations of an artificially prepared 'seston', while in the field, they were exposed to fluctuating amounts of natural seston.

\section{MATERIALS AND METHODS}

Collection of test organisms. Thirty adult specimens of Mulinia edulis (length $50.22 \pm 0.67 \mathrm{~mm}$; dry weight $1.36 \pm 0.36 \mathrm{~g})$ and Mytilus chilensis (length $50.72 \pm 0.67 \mathrm{~mm}$; dry weight $1.04 \pm 0.36 \mathrm{~g}$ ) were obtained from natural populations on the tidal flat of Yaldad Bay $\left(43^{\circ} 06^{\prime} \mathrm{S}, 73^{\circ} 44^{\prime} \mathrm{W}\right)$, Chiloé, Chile (Fig. 1). This bay is characterized by an extensive tidal flat with a $5 \%$ slope, and has an area of about $1 \mathrm{~km}^{2}$ at low tide and a tidal amplitude of about $5 \mathrm{~m}$ (Clasing et al. 1998). The salinity range is about 24 to $31 \mathrm{ppt}$, the temperature is between 9 and $16^{\circ} \mathrm{C}$, and the average monthly seston concentrations are about $3.7 \mathrm{mg} \mathrm{l}^{-1}$ (end of summer, winter) and $48 \mathrm{mg} \mathrm{l}^{-1}$ (end of spring, beginning of summer; Navarro et al. 1993).
Experimental design. Feeding rate parameters were measured in 8 bivalves of each species (chosen haphazardly), using 16 artificial seston concentrations of between 3 and $203 \mathrm{mg} \mathrm{l}^{-1}$ in the laboratory, and 8 natural seston concentrations from 3 to $665 \mathrm{mg} \mathrm{l}^{-1}$ in situ on the Yaldad tidal flat. Water temperature $\left(14^{\circ} \mathrm{C}\right)$ and salinity (32 ppt) were similar in both laboratory and in situ experiments. The experimental diets were administered using a flow-through system consisting of 18 chambers, designed following Riisgård (1977). A constant flow $\left(150 \pm 10 \mathrm{ml} \mathrm{min}^{-1}\right)$ of the experimental diet (natural or artificial) was directed by gravity from a mixing tank into each chamber; 16 chambers were used for individual bivalves (8 individuals of each species) and 2 chambers contained empty valves which served as controls. Valve opening by test specimens was continually observed and individuals which failed to open normally were eliminated from the experiment.

For the laboratory experiments, the bivalves were transported wet to the laboratory located on the bay, where they were acclimated for experimentation in a flow-through seawater system at $14^{\circ} \mathrm{C}$ and $30 \mathrm{ppt}$ salinity for $1 \mathrm{wk}$. The seawater was dosed with laboratory cultured Isochrysis galbana as food, at a concentration which was below the threshold of pseudofeces production (between 2 and $2.5 \mathrm{mg} \mathrm{l}^{-1}$, Velasco \& Navarro 2002). Artificial diets were prepared by mixing cultivated microalgae (I. galbana) and natural sediment collected from the top $\mathrm{cm}$ of surface sediment on the Yaldad tidal flat. As a preparative step, the sediment was screened through a $40 \mathrm{~mm}$ aperture nylon 
screen and homogenized in filtered seawater. The microalgae used to prepare the diets had spherical diameters between 3 and $7 \mathrm{~mm}$. The sediment particles (13 to $15 \%$ organic matter) measured between 3 and $13 \mathrm{~mm}$, as determined by an ELZONE $180 \mathrm{XY}$ particle counter using a $120 \mathrm{~mm}$ aperture tube. Artificial diets with different concentrations and compositions were prepared by mixing appropriate volumes of microalgae suspensions, sediment and filtered seawater. Each experiment lasted $5 \mathrm{~h}$, with the first $2 \mathrm{~h}$ used for acclimation of the organisms to the diet and the following $3 \mathrm{~h}$ for physiological measurements. The diet acclimation time was taken as the period required for the ingested particles to be eliminated as feces, thus assuring that the digestive tract contained the experimental diet which had been administered (Velasco \& Navarro 2002).

The in situ experiments were carried out at the end of summer 1999 on the tidal flat of Yaldad Bay over 2 tidal cycles, one on 27 March and the other on 4 April. Bivalve specimens obtained from natural populations were placed directly into the same 18 chamber flowthrough system cited above, which had been mounted on a mussel-culture raft. The experimental diet used was pumped from $8 \mathrm{~cm}$ above the bottom and filtered through a $150 \mathrm{~mm}$ screen prior to reaching the experimental individuals.

Characterization of seston. The seston content of each experimental diet was analyzed in terms of total particulate matter (TPM) and particulate organic matter (POM). Water was sampled from the outflow of both control chambers every half hour in situ and every hour in the laboratory. Each sample was divided into 3 subsamples which were filtered onto tared Millipore glass fiber filters $(\varnothing=0.45 \mathrm{~mm})$ which had been prewashed in distilled water and pre-ashed at $450^{\circ} \mathrm{C}$ for $4 \mathrm{~h}$. Filters with samples were rinsed with isotonic ammonium formate to remove salt and prevent cell lysis, and were dried at $70^{\circ} \mathrm{C}$ for $48 \mathrm{~h}$ to determine the TPM $\left(\mathrm{mg} \mathrm{l}^{-1}\right)$. POM $\left(\mathrm{mg} \mathrm{l}^{-1}\right)$ was determined as the loss in weight of the samples after ashing at $450^{\circ} \mathrm{C}$ for $4 \mathrm{~h}$.

Physiological determinations. Physiological variables were determined with the biodeposition method described by Iglesias et al. (1998) and validated by Navarro \& Velasco (2003), using the 'flow-through chamber method' described by Riisgård (2001). Feces and pseudofeces were quantitatively collected every $2 \mathrm{~h}$ using Pasteur pipettes. The mass and organic content of the material deposited by each test bivalve were estimated separately using the method described above for the seston. When the quantity of sedimented food material on the bottom of the chambers made the separation of pseudofeces impossible, both sedimented food particles and pseudofeces were collected from the chambers. The mass and organic content of pseudofe- ces were determined by subtraction of the material collected in the control chambers from that of each of the experimental chambers. In situ feeding rates were determined by quantifying fecal production per unit time in relation to the seston content of the water $2 \mathrm{~h}$ prior to the determination, since this is the time period required for unabsorbed matter to be passed through the digestive tracts of the bivalves (Velasco \& Navarro 2002). The equations for the physiological variables were the same as those used by Iglesias et al. (1998).

Clearance rate (CR): is the volume of water completely cleared of particles per unit time.

$$
\mathrm{CR}\left(\mathrm{l} \mathrm{h}^{-1}\right)=\mathrm{IFR} / \mathrm{PIM}
$$

where IFR is the inorganic filtration rate $\left(\mathrm{mg} \mathrm{l}^{-1}\right)$ and PIM is the particulate inorganic matter $\left(\mathrm{mg} \mathrm{l}^{-1}\right)$.

Filtration rate (FR): represents the amount of particulate material removed from the water per unit time.

$$
\begin{gathered}
\text { IFR }\left(\mathrm{mg} \mathrm{h}^{-1}\right)=\mathrm{IRR}+\mathrm{IER} \\
\text { OFR }\left(\mathrm{mg} \mathrm{h}^{-1}\right)=\mathrm{IFR} \times(\mathrm{POM} / \mathrm{PIM}) \\
\text { FR }\left(\mathrm{mg} \mathrm{h}^{-1}\right)=\mathrm{IFR}+\mathrm{OFR}
\end{gathered}
$$

where IRR is the production rate of pseudofeces inorganic matter $\left(\mathrm{mg} \mathrm{h}^{-1}\right)$, IER is the production rate of feces inorganic matter $\left(\mathrm{mg} \mathrm{h}^{-1}\right)$, OFR is the organic filtration rate and $\mathrm{FR}$ is the total filtration rate.

Efficiency of preingestive selection (SE): The efficiency with which particles with higher organic content were retained for ingestion was calculated after Bayne et al. (1993) as:

$$
\mathrm{SE}=1-(\% \mathrm{OR} / \% \mathrm{POM}) \times 100
$$

where $\% O R$ is the percentage of organic matter in pseudofeces and \%POM is the percentage of particulate organic matter in ambient water.

Ingestion rate: When no pseudofeces are produced, the total filtration and organic matter filtration rates are represented, respectively, by the total ingestion (IR) and organic ingestion rates (OIR). When pseudofeces are produced, the IR is calculated by subtraction of the pseudofeces production rate from the FR (Bayne et al. 1993):

$$
\begin{gathered}
\text { IR }\left(\mathrm{mg} \mathrm{h}^{-1}\right)=\mathrm{FR}-\mathrm{RR} \\
\text { OIR }\left(\mathrm{mg} \mathrm{h}^{-1}\right)=\mathrm{OFR}-\mathrm{ORR}
\end{gathered}
$$

where RR is the production rate of total pseudofeces $\left(\mathrm{mg} \mathrm{h}^{-1}\right)$ and ORR is the production rate of pseudofeces organic matter $\left(\mathrm{mg} \mathrm{h}^{-1}\right)$.

Absorption efficiency (AE) and rate (AR): represent material ingested and absorbed per unit time.

$$
\begin{gathered}
\mathrm{AE}(\%)=\mathrm{AR} /(\mathrm{OFR}-\mathrm{ORR}) \times 100 \\
\mathrm{AR}\left(\mathrm{mg} \mathrm{h}^{-1}\right)=\mathrm{OIR}-\mathrm{OER}
\end{gathered}
$$

where OER is the production rate of feces organic matter $\left(\mathrm{mg} \mathrm{h}^{-1}\right)$. 
Standardization of variables. The physiological rates were converted to a 'standard' individual of $1 \mathrm{~g}$ tissue weight after Bayne et al. (1987). Soft tissues were dried at $70^{\circ} \mathrm{C}$ for $48 \mathrm{~h}$ and then individually weighed. Standardization employed the equation described by Bayne et al. (1987):

$$
Y_{\mathrm{s}}=\left(W_{\mathrm{s}} / W_{\mathrm{e}}\right)^{b} \times Y_{\mathrm{e}}
$$

where $Y_{\mathrm{S}}$ is the $\mathrm{CR}$ for an individual of standard weight, $W_{\mathrm{s}}$ is the standard organism weight, $W_{\mathrm{e}}$ is the observed organism weight, $Y_{\mathrm{e}}$ is the uncorrected measured $\mathrm{CR}$ and $b$ is the weight exponent. The weight exponents for CR were 0.5 and 0.61 for Mulinia edulis and Mytilus chilensis, respectively (Velasco \& Navarro 2002).

Statistical analyses. Simple linear and nonlinear regressions were carried out to examine the dependence of each of the physiological variables on TPM and 'best models' were selected on the basis of the major determination coefficient $\left(\mathrm{r}^{2}\right)$. Analysis of covariance (ANCOVA) was also applied to detect differences between laboratory and in situ physiological rates, transformed in order to comply with the assumptions of normality and homocedasticity $\left(\log _{10}\right.$ transformation was applied to $C R, F R, I R$ and $A R$, and arcsine transformation to $S E$ and AE data). Finally, a 1-way ANOVA was carried out to reveal any differences between the organic fraction of the food (\%MOP) and that of the pseudofeces produced by Mulinia edulis and Mytilus chilensis (\%OR). Statistical calculations were carried out using the general linear model procedure (GLM) of the SAS 6.1 program (SAS Institute). An $\alpha=0.05$ was used for making all decisions concerning level of significance.

\section{RESULTS}

\section{Natural seston}

Concentrations of naturally occurring seston varied between 2.53 and $665 \mathrm{mg} \mathrm{l}^{-1}$ during the experiments at Yaldad Bay (Fig. 2A). The highest concentrations were found after the tide reached its lowest point, with concentrations higher than $100 \mathrm{mg} \mathrm{l}^{-1}$ occurring in the presence of southerly winds.

Seston organic content varied between 21 and $31 \%$; the highest values coincided with the lowest total seston concentrations $\left(2.86 \mathrm{mg} \mathrm{l}^{-1}\right)$ and the lowest coincided with the highest concentrations $\left(665 \mathrm{mg} \mathrm{l}^{-1}\right)$. A significant negative correlation was observed between these 2 parameters (Fig. 2B), similar to the results obtained in the laboratory experiments (Fig. 2B).
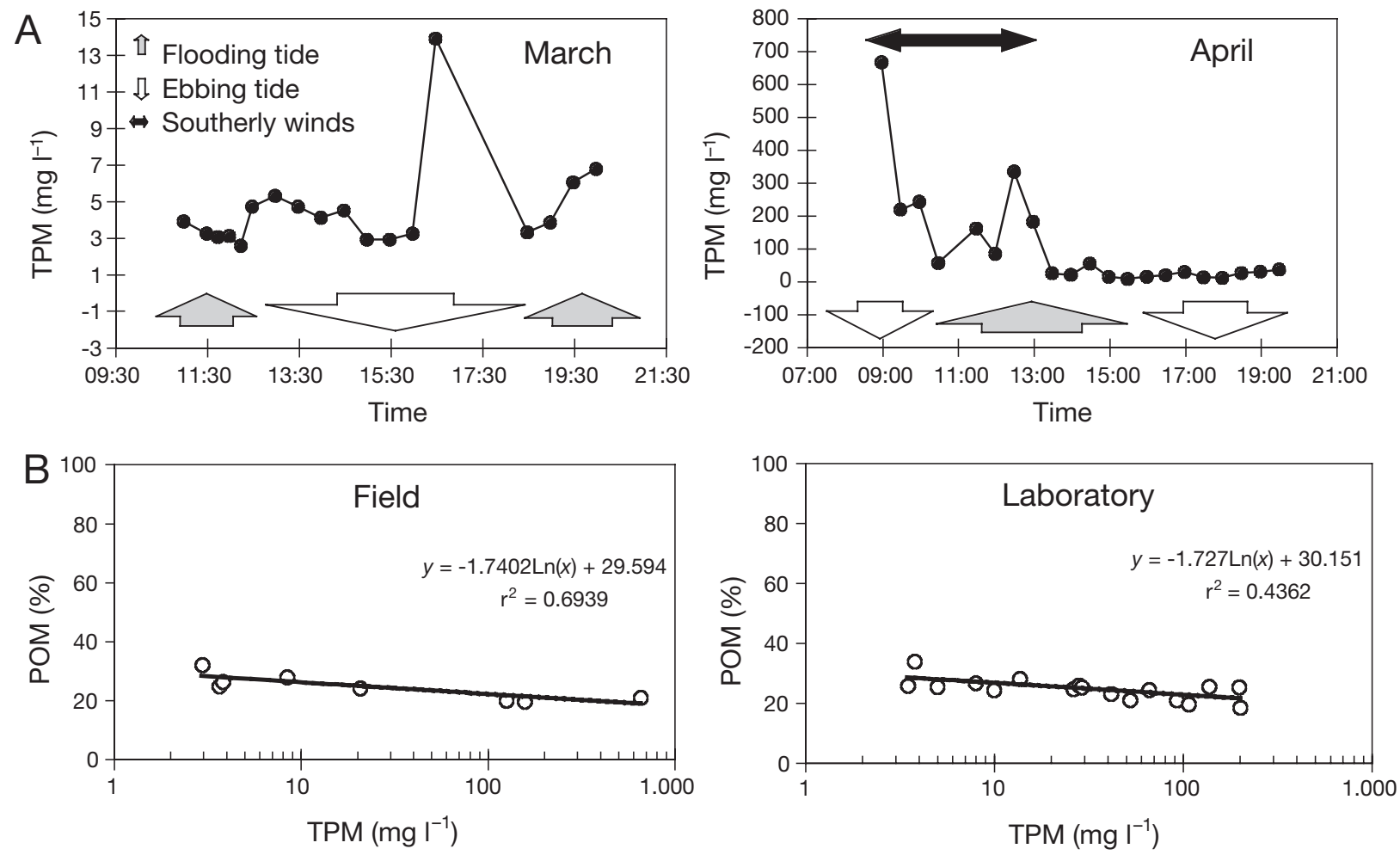

Fig. 2. (A) Concentration of seston on the Yaldad Bay tidal flat over 2 tidal cycles in 1999: 27 March and 4 April. (B) Relation between the seston concentration (TPM) and quality (POM) employed in the experiments in situ and in the laboratory 


\section{Physiological variables}

Clearance rate

Laboratory measurements indicated that the CR for Mulinia edulis varied between 0.55 and $1.76 \mathrm{l} \mathrm{h}^{-1}$, while that for Mytilus chilensis was between 0.28 and $3.74 \mathrm{l} \mathrm{h}^{-1}$. In field conditions, the CR for $M$. edulis was between 0.02 and $1.90 \mathrm{l} \mathrm{h}^{-1}$, while that for $M$. chilensis was between 0.08 and $4.97 \mathrm{l} \mathrm{h}^{-1}$. In both cases this rate decreased exponentially with an increase in TPM in ambient water (Fig. 3A). The regression equations which best described the trends in CR are given in Table 1. The ANCOVA showed that the CR values obtained in the laboratory for both species were not significantly different from those determined in the field (Table 2).

Filtration rate

The mean FR of Mulinia edulis varied between 2.8 and $127.3 \mathrm{mg} \mathrm{h}^{-1}$ in the laboratory and between 3.6 and $106.3 \mathrm{mg} \mathrm{h}^{-1}$ in the field. That of Mytilus chilensis was between 7.6 and $201.2 \mathrm{mg} \mathrm{h}^{-1}$ in the laboratory and 9.8 and $75.3 \mathrm{mg} \mathrm{h}^{-1}$ in the field. This rate increased in both species with an increase in TPM, both in the laboratory and in the field, although the rate decreased at the highest concentrations (Fig. 3B, Table 1). The ANCOVA showed that the FRs determined in the laboratory were statistically higher than those obtained in the field for both species (Table 2).
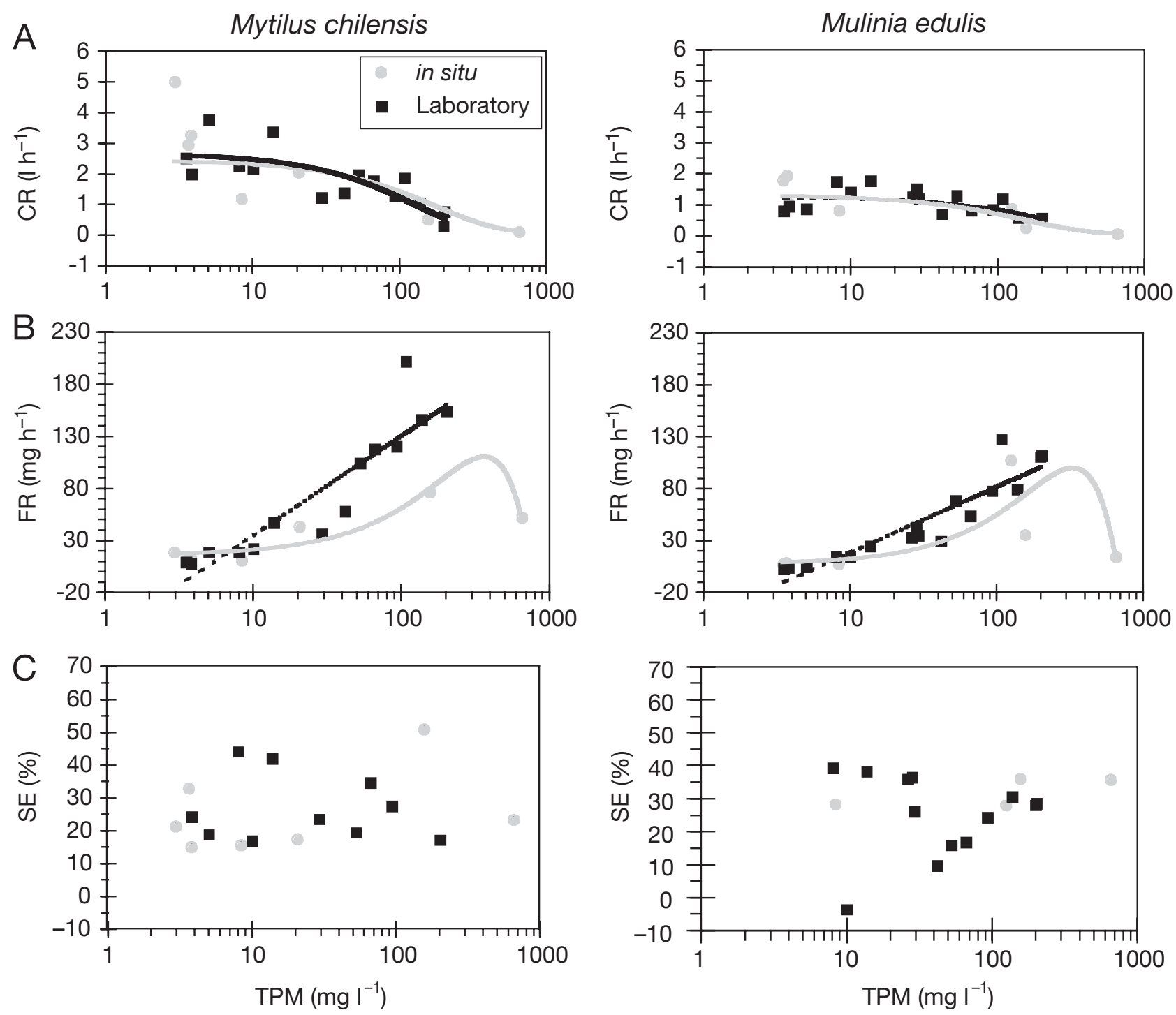

Fig. 3. Mulinia edulis and Mytilus chilensis. Relation between the seston concentration (TPM) and (A) clearance rate (CR), (B) filtration rate (FR) and (C) selection efficiency (SE) in the laboratory and in situ 
Table 1. Mulinia edulis and Mytilus chilensis. Regressions between seston concentration (TPM) and feeding rates in situ and the laboratory (in lab). CR: clearance rate; FR: filtration rate; IR: total ingestion rate; AE: absorption efficiency; AR: absorption rate

\begin{tabular}{|c|c|c|}
\hline Eq. & $\mathrm{r}^{2}$ & $\mathrm{p}<$ \\
\hline \multicolumn{3}{|l|}{ M. edulis } \\
\hline CR in situ $=1.2423 \mathrm{e}^{-0.0064 \times \mathrm{TPM}}$ & 0.918 & 0.050 \\
\hline $\mathrm{CR}$ in lab $=1.2522 \mathrm{e}^{-0.004 \times \mathrm{TPM}}$ & 0.472 & 0.050 \\
\hline FR in situ $=0.595435 \times \mathrm{TPM}-0.00086674 \times \mathrm{TPM}^{2}$ & 0.5771 & 0.050 \\
\hline FR in lab $=1.23494 \times \mathrm{TPM}-0.00346168 \times \mathrm{TPM}^{2}$ & 0.8956 & 0.050 \\
\hline IR in situ $=-0.00003 \mathrm{TPM}^{2}+0.0148 \mathrm{TPM}+5.1001$ & 0.5832 & 0.050 \\
\hline IR in lab $=5.8705+0.195046 \times \mathrm{TPM}-0.000746899 \times \mathrm{TPM}^{2}$ & 0.6917 & 0.002 \\
\hline $\mathrm{AE}$ in situ $=31.709+6.8968 \times \operatorname{Ln}(\mathrm{TPM})$ & 0.6063 & 0.039 \\
\hline $\mathrm{AE}$ in lab $=2.57467+16.3619 \times \operatorname{Ln}(\mathrm{TPM})$ & 0.7718 & 0.050 \\
\hline $\mathrm{AR}$ in situ $=0.025676 \times \mathrm{TPM}-0.0000370732 \times \mathrm{TPM}^{2}$ & 0.5659 & 0.050 \\
\hline AR in lab $=-2.9534+1.9553 \times \operatorname{Ln}(\mathrm{TPM})$ & 0.8354 & 0.002 \\
\hline \multicolumn{3}{|l|}{ M. chilensis } \\
\hline CR in situ $=2.3841 \mathrm{e}^{-0.0054 \times \mathrm{TPM}}$ & 0.8466 & 0.050 \\
\hline $\mathrm{CR}$ in $\mathrm{lab}=2.616 \mathrm{e}^{-0.0078 \times \mathrm{TPM}}$ & 0.7134 & 0.050 \\
\hline FR in situ $=14.214+0.5057 \times \mathrm{TPM}-0.0007 \times \mathrm{TPM}^{2}$ & 0.8862 & 0.046 \\
\hline FR in lab $=2.1595 \times \mathrm{TPM}-0.006933 \times \mathrm{TPM}^{2}$ & 0.9109 & 0.001 \\
\hline $\mathrm{IR}$ in situ $=3.0444+0.04137 \times \mathrm{TPM}-0.00004811 \times \mathrm{TMP}^{2}$ & 0.8686 & 0.050 \\
\hline $\mathrm{IR}$ in lab $=\mathrm{e}^{(1.57194+0.0149075 \times \mathrm{TPM}-0.0000547 \times \mathrm{TPM} 2)}$ & 0.7323 & 0.010 \\
\hline $\begin{array}{l}\mathrm{AE} \text { in situ }=100 \times \sin (0.58906+0.00596 \times \mathrm{TPM}- \\
\left.\quad 0.00001 \times \mathrm{TPM}^{2}\right)\end{array}$ & 0.6680 & 0.048 \\
\hline $\begin{array}{l}\mathrm{AE} \text { in lab }=100 \times \sin (0.572003+0.00873 \times \mathrm{TPM}- \\
\left.\quad 0.00004 \times \mathrm{TPM}^{2}\right)\end{array}$ & 0.5283 & 0.03 \\
\hline AR in situ $=0.0637981 \times \mathrm{TPM}-0.0000901013 \times \mathrm{TPM}^{2}$ & 0.8950 & 0.050 \\
\hline $\begin{array}{l}\mathrm{AR} \text { in lab }=(1.03874+0.02806 \times \mathrm{TPM}- \\
\left.\quad 0.000113912 \times \mathrm{TPM}^{2}\right)^{2}\end{array}$ & 0.6458 & 0.012 \\
\hline
\end{tabular}

Table 2. Mulinia edulis and Mytilus chilensis. ANCOVA for physiological variables (GLM procedure; model: physiological variable $=$ condition TPM). $\mathrm{p}>|\mathrm{T}|$ $\mathrm{H}_{0}$ : probability of getting a larger $|\mathrm{T}|$ value under the hypothesis (a very small value for this probability leads to the conclusion that the independent variable contributes significantly to the model.). LS mean: least-square mean. For other abbreviations see Table 1

\begin{tabular}{|c|c|c|c|c|c|c|}
\hline & $\begin{array}{l}\text { Vari- } \\
\text { able }\end{array}$ & Condition & $\begin{array}{c}\text { LS } \\
\text { mean }\end{array}$ & $\begin{array}{l}\text { Standard } \\
\text { error } \\
\text { LS mean }\end{array}$ & $\begin{array}{c}\mathrm{p}>|\mathrm{T}| \mathrm{H}_{0}: \\
\text { LS mean } \\
\quad=0\end{array}$ & $\begin{array}{c}\mathrm{p}>|\mathrm{T}| \mathrm{H}_{0}: \\
\mathrm{LS} \text { mean }(1)= \\
\mathrm{LS} \text { mean }(2)\end{array}$ \\
\hline \multirow[t]{12}{*}{ M. edulis } & \multirow[t]{2}{*}{$\mathrm{CR}$} & (1) In situ & 1.17 & 0.09 & 0.0001 & \multirow[t]{2}{*}{0.3080} \\
\hline & & (2) In lab & 1.06 & 0.06 & 0.0001 & \\
\hline & \multirow[t]{2}{*}{ FR } & (1) In situ & 16.33 & 5.35 & 0.0027 & \multirow[t]{2}{*}{0.0009} \\
\hline & & (2) In lab & 43.57 & 3.52 & 0.0001 & \\
\hline & \multirow[t]{2}{*}{ SE } & (1) In situ & 31.72 & 4.00 & 0.0001 & \multirow[t]{2}{*}{0.2496} \\
\hline & & (2) In lab & 26.54 & 1.79 & 0.0001 & \\
\hline & \multirow[t]{2}{*}{ IR } & (1) In situ & 5.12 & 0.81 & 0.0001 & \multirow[t]{2}{*}{0.0001} \\
\hline & & (2) In lab & 11.16 & 0.53 & 0.0001 & \\
\hline & \multirow[t]{2}{*}{$\mathrm{AE}$} & (1) In situ & 45.01 & 4.14 & 0.0001 & \multirow[t]{2}{*}{0.0400} \\
\hline & & (2) In lab & 55.15 & 2.55 & 0.0001 & \\
\hline & \multirow[t]{2}{*}{$\mathrm{AR}$} & (1) In situ & 0.81 & 0.40 & 0.0481 & \multirow[t]{2}{*}{0.0001} \\
\hline & & (2) In lab & 3.32 & 0.25 & 0.0001 & \\
\hline \multirow[t]{12}{*}{ M. chilensis } & CR & (1) In situ & 2.59 & 0.20 & 0.0001 & \multirow[t]{2}{*}{0.3261} \\
\hline & & (2) In lab & 2.03 & 0.12 & 0.0001 & \\
\hline & \multirow[t]{2}{*}{ FR } & (1) In situ & 33.19 & 8.74 & 0.0001 & \multirow[t]{2}{*}{0.0009} \\
\hline & & (2) In lab & 69.15 & 5.56 & 0.0001 & \\
\hline & \multirow[t]{2}{*}{$\mathrm{SE}$} & (1) In situ & 21.43 & 2.65 & 0.0001 & \multirow[t]{2}{*}{0.5216} \\
\hline & & (2) In lab & 29.32 & 1.32 & 0.0001 & \\
\hline & \multirow[t]{2}{*}{ IR } & (1) In situ & 3.59 & 0.58 & 0.0001 & \multirow[t]{2}{*}{0.0001} \\
\hline & & (2) In lab & 8.10 & 0.38 & 0.0001 & \\
\hline & \multirow[t]{2}{*}{$\mathrm{AE}$} & (1) In situ & 54.10 & 3.72 & 0.0001 & \multirow[t]{2}{*}{0.0008} \\
\hline & & (2) In lab & 69.45 & 2.41 & 0.0001 & \\
\hline & \multirow[t]{2}{*}{$\mathrm{AR}$} & (1) In situ & 1.14 & 0.48 & 0.0199 & \multirow[t]{2}{*}{0.0001} \\
\hline & & (2) In lab & 3.96 & 0.31 & 0.0001 & \\
\hline
\end{tabular}

\section{Selection efficiency}

The SE of Mulinia edulis varied between 3.7 and $39.3 \%$ in the laboratory and between 28 and $36 \%$ in the field. In Mytilus chilensis, this variable was between 17 and $44 \%$ in the laboratory, and 15 and $51 \%$ in the field. Fig. 3C shows that there was no relation between the SE and TPM for either species. The ANCOVA showed no significant differences in SE between conditions (Table 2).

Particles emitted as pseudofeces by both species had an organic content that was significantly less than that of the food particles ( $p=0.001$; Fig. 4) in both laboratory and field measurements.

\section{Ingestion rate}

The IR measured in the laboratory varied between 2.8 and $20.1 \mathrm{mg} \mathrm{h}^{-1}$ for Mulinia edulis and between 3.7 and $15.4 \mathrm{mg} \mathrm{h}^{-1}$ for Mytilus chilensis. In the field, this rate was between 1.8 and $7.2 \mathrm{mg} \mathrm{h}^{-1}$ for $M$. edulis, while it varied between 1.8 and $9.3 \mathrm{mg} \mathrm{h}^{-1}$ for $M$. chilensis. The total material ingested by both species increased with an increase in TPM, but decreased at high TPM, adjusting to polynomial relationships (Fig. 5A, Table 1). The ANCOVA showed that the IR measured in the laboratory was greater than that measured in the field for both species (Table 2).

\section{Absorption efficiency and rate}

AE values in the field varied between 22 and $67 \%$ for Mulinia edulis and between 39 and $96 \%$ for Mytilus chilensis. In the laboratory, the $\mathrm{AE}$ of $M$. edulis varied between 3 and $92 \%$ and that of M. chilensis between 14 and $90 \%$. The AE increased with TPM, but in $M$. chilensis it decreased at high seston concentration (Fig. 5B, Table 1). The values obtained for both species in the field were significantly lower than those measured in the laboratory (Table 2).

Mulinia edulis showed AR values between 0.05 and $9.13 \mathrm{mg} \mathrm{h}^{-1}$ in the laboratory, and 0.42 and $3.98 \mathrm{mg} \mathrm{h}^{-1}$ in 


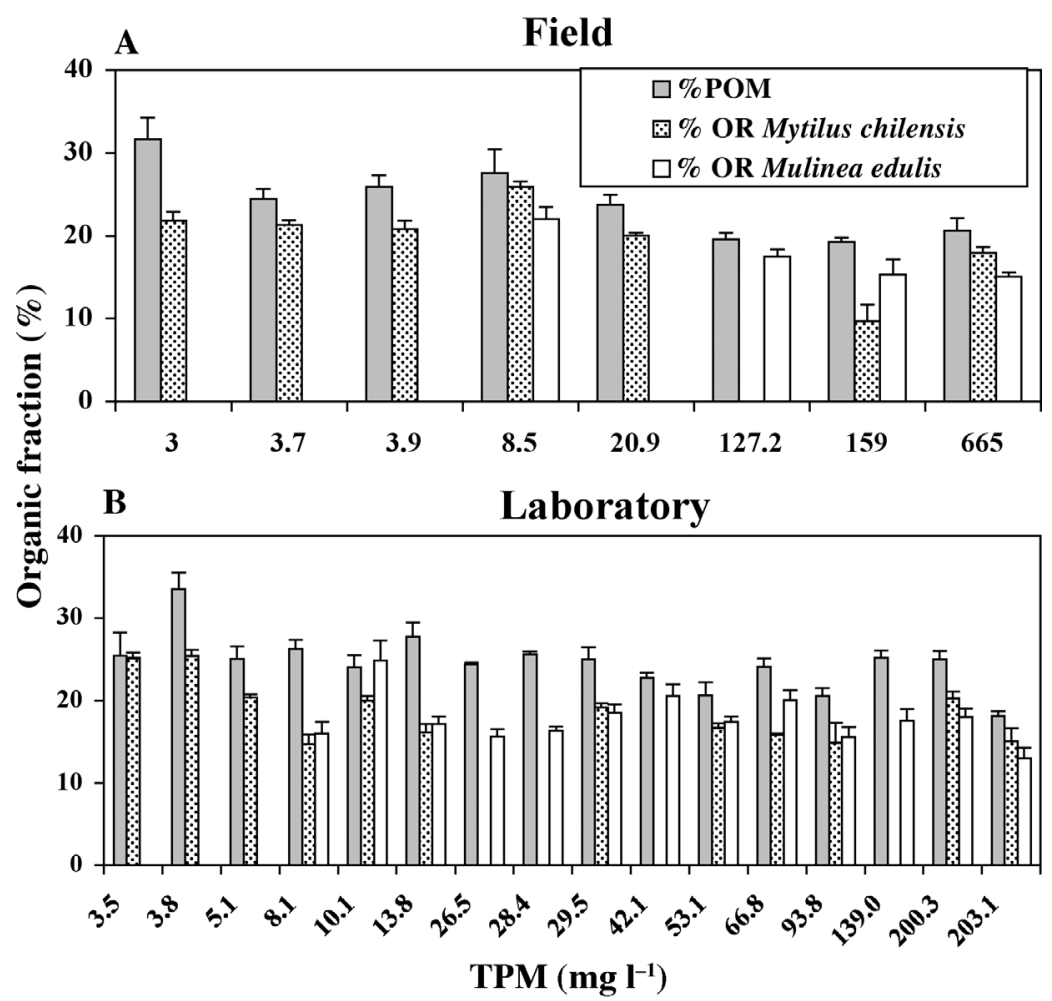

Fig. 4. Mulinia edulis and Mytilus chilensis. Organic content of seston (POM) and pseudofeces produced in (A) the field and (B) the laboratory

Although the CR measured in laboratory and field were similar, FR and IR were higher when measured in the laboratory, suggesting that there were fewer particles in the natural seston that the bivalves were capable of efficiently retaining. According to Vahl (1973), retention efficiency is less than $100 \%$ when the particles are smaller than $2 \mu \mathrm{m}$. Factors including form, hardness, particle type and species of microalgae (planktonic or benthic) also affect the retention efficiency of particles (Shumway et al. 1985, Bougrier et al. 1997). Since diets administered in the field and the laboratory had similar TPM and \%POM (Fig. 2B), differing only in the types of microalgae present (Isochrysis galbana in the laboratory and a variety of species in the field), the similarity of the SE values obtained under both conditions suggests that the preingestive processing of particles was more affected by their organic matter content than by the types of phytoplankton present in the seston. The higher values of AE obtained in the laboratory suggest that I. galbana contained more digestible components

the field (Fig. 5C). Values for Mytilus chilensis were between 0.15 and $10.72 \mathrm{mg} \mathrm{h}^{-1}$ in the laboratory and between 0.25 and $7.69 \mathrm{mg} \mathrm{h}^{-1}$ in the field. The AR of both species increased with TPM and decreased at high TPM, except that of $M$. edulis in the laboratory (Table 1). The in situ AR estimated for both species were significantly lower than those measured in the laboratory (Table 2).

\section{DISCUSSION}

Three important points emerged in this study: (1) with the exception of the CR and SE, the physiological rates (FR, IR, AE and AR) measured in the field were lower than those in the laboratory under similar conditions; (2) in both field and laboratory, the relation between physiological rates and variations in seston concentration were similar for the 2 species, although the TPM threshold at which decreases occurred was lower in the laboratory; and (3) the highest values of TPM and lowest values of \% POM were observed in the presence of southerly winds over Yaldad Bay and prior to the occurrence of the lowest tide level, due to resuspension of fine sediment from the bottom. than those found in the natural environment and/or that the enzymatic systems of both species became adapted to the diets administered in the laboratory during the acclimation period ( $>1 \mathrm{wk}$ ), resulting in better digestion. Labarta et al. (2002) showed that the digestive enzyme activity of Mulinia edulis and Mytilus chilensis from the intertidal zone increased after a $7 \mathrm{~d}$ period of acclimation to relatively constant dietary conditions, when the bivalves were maintained suspended beneath culture rafts.

In summary, the lower values of FR, IR and AR measured in situ suggest the occurrence of microalgae in natural seston that were not retained with $100 \%$ efficiency. The greater AE and AR values obtained in the field indicate that Isochrysis galbana is more digestible than microalgae in natural seston and/or that the digestive enzymes in bivalves maintained in the laboratory had a greater activity as a result of the relatively long period of acclimation to the diet.

The relations between the feeding responses of Mulinia edulis and Mytilus chilensis in the field and laboratory and the TPM were similar. This is in agreement with results obtained in previous studies with the same species (Velasco \& Navarro 2002, 2003) and with others (Iglesias et al. 1992, Bayne et al. 1993, Hawkins et al. 1996, 1998, Navarro et al. 1996, Barillé et al. 1997, 

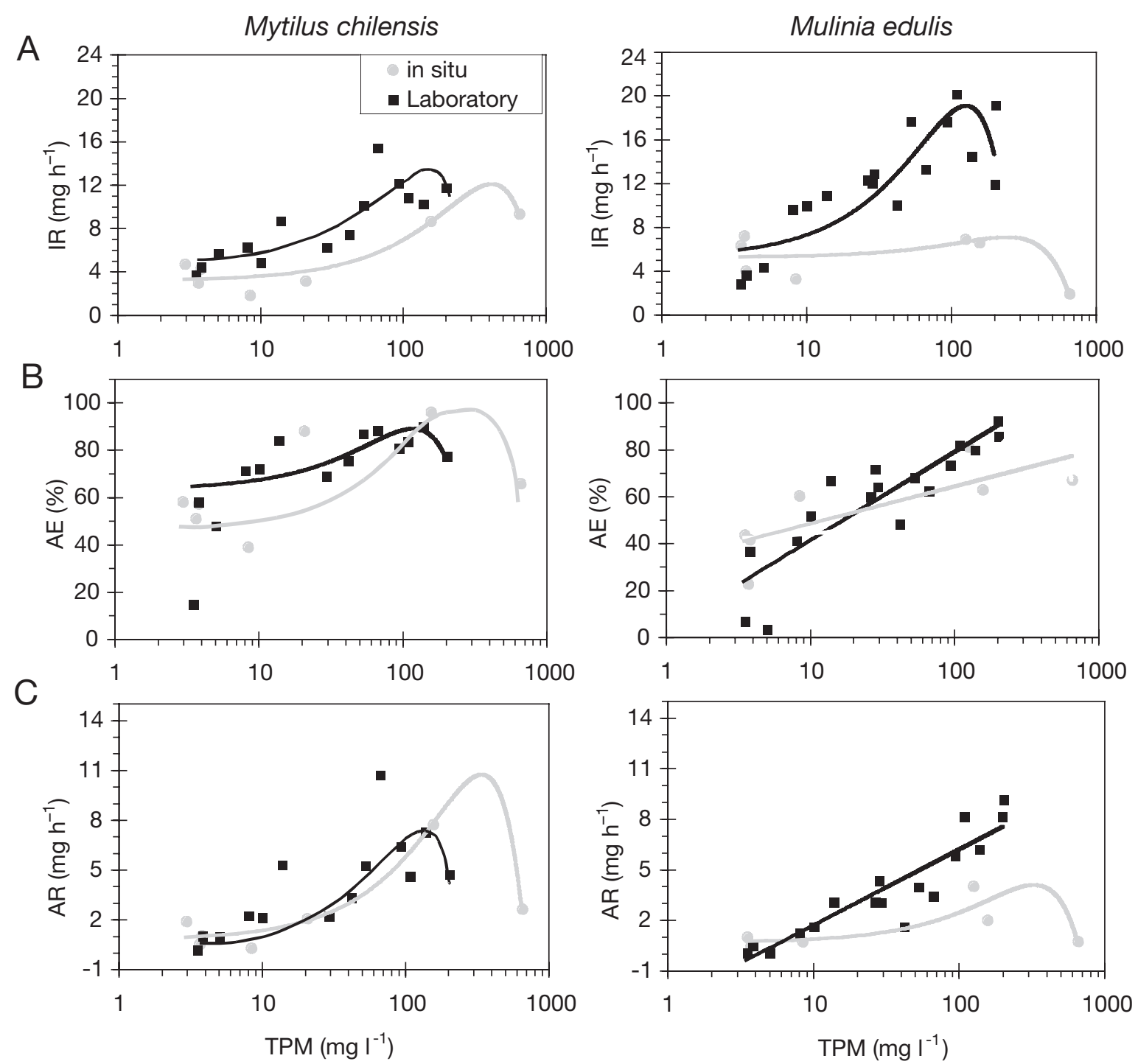

Fig. 5. Mulinia edulis and Mytilus chilensis. Relation between the seston concentration (TPM) and (A) ingestion rate (IR), (B) absorption efficiency (AE) and (C) absorption rate (AR) in the laboratory and in situ

Bacon et al. 1998), but disagrees with those of Urrutia et al. (1996), who reported an increase in CR in Cerastoderma edule with rising natural TPM. The TPM threshold at which the physiological rates decreased was lower in the laboratory (approx. $200 \mathrm{mg} \mathrm{l}^{-1}$ ) in comparison with that in the field (approx. $665 \mathrm{mg} \mathrm{l}^{-1}$ ). This is explained by the higher rates of food processing in the laboratory, which caused saturation of the digestive tract at low TPM concentrations. This hypothesis also explains the lack of decrease in the AR of $M$. edulis at high TPM in the laboratory. The low feeding rate of $M$. edulis prevents saturation of its digestive system at $200 \mathrm{mg} \mathrm{l}^{-1} \mathrm{TPM}$ and the AR remains relatively constant, in contrast to $M$. chilensis under the same conditions.
The present results suggest that, in studies designed to approach true values for feeding rates in bivalves, it is most appropriate to make the measurements using natural seston present in the organism's habitat. For studies in which the objective is the determination of variations in physiological responses to specific factors, laboratory studies under controlled conditions may be more appropriate for various reasons, including: (1) extraneous variables can be controlled or prevented from interfering with results, and (2) laboratory results may be similar to those obtained in the field as long as the methods are correctly applied and identical among treatments. Values may be obtained with more precision if retention efficiencies and particle absorption values from field mea- 
surements are used for correction of the laboratory results.

In the absence of wind, the seston concentrations on the Yaldad Bay tidal flat were relatively low and constant (e.g. 3.7 to $48 \mathrm{mg} \mathrm{l}^{-1}$ ), as previously reported by Widdows et al. (1979), Anderson \& Meyer (1986) and Navarro et al. (1993). Under the influence of strong southerly winds, the seston concentrations at Yaldad became quite high and variable ( 55 to $665 \mathrm{mg} \mathrm{l}^{-1}$ ), placing them among the highest values recorded, which include, for example, values of $130 \mathrm{mg} \mathrm{l}^{-1}$ (Rio Queule, Chile; Rojas 1984), $500 \mathrm{mg} \mathrm{l}^{-1}$ (Humber Estuary, England; Falconer \& Owens 1990), and 95 and $350 \mathrm{mg} \mathrm{l}^{-1}$ (Marennes Bay, Oléron, France; Urrutia et al. 1996). Although wind events do not normally last longer than $6 \mathrm{~h}$, these events may be frequent in this area, producing short-term (h) fluctuations in seston concentrations which greatly exceed typical mean variations when measured over month-long periods (Navarro et al. 1993). The inverse correlation between seston concentration and its quality, and the coincidence of southerly winds with the higher concentrations on the Yaldad tidal flat, show that the broad fluctuations in seston concentrations are due to the resuspension of sediments from the bottom. Sediment contains a larger fraction of inorganic material (average $87 \%$ ), and when it is resuspended, the organic fraction assumes a smaller percentage value of the total. Seston concentrations were highest after the lowest point of the tide, contrasting with most previous studies of natural seston in which the highest concentrations were observed in a rising tide (Fegley et al. 1992, Stenton-Dozey \& Brown 1992, Urrutia et al. 1996). Our results are confirmed, however, by other studies made at the same site, suggesting that the observation is the result of local, site-specific low-tide currents (Navarro et al. 1993).

In conclusion, bivalves in the unique intertidal flat environments of southern Chile are confronted with the highly stressful trophic conditions in which potential food materials may become highly diluted by large quantities of inorganic particles mixed into the water by the effect of strong (southerly) winds acting on long stretches of shoal water over broad expanses of tidal flat at low tide. Our results suggest that local clams and mussels (Mulinia edulis and Mytilus chilensis) have adapted to deal with this stress by evolving mechanisms that allow them to obtain energy from the highly diluted particulate organic matter, even through winter seasons of low primary productivity.

Acknowledgements. The authors gratefully acknowledge E. Díaz and M. Araneda for their help during the experiments. Thanks are also due to the staff of the field station at Yaldad, Chiloé, where most of the experimental work was done. This study was supported by a research grant to J.M.N. (FONDE-
CYT 1000427), by a doctoral thesis research grant (DID, Universidad Austral de Chile D-99-01) and by a fellowship to L.A.V. from the DAAD (Deutscher Akademischer Austauschdienst, Programmabteilung Süd).

\section{LITERATURE CITED}

Anderson FE, Meyer LM (1986) The interaction of tidal currents on disturbed intertidal bottom with a resulting change in particulate matter quantity, temperature and food quality. Estuar Coast Shelf Sci 22:19-29

Bacon GS, MacDonald BA, Ward JE (1998) Physiological responses of infaunal (Mya arenaria) and epifaunal (Placopecten magellanicus) bivalves to variations in the concentration and quality of suspended particles. I. Feeding activity and selection. J Exp Mar Biol Ecol 219:105-125

Barillé L, Prou J, Hérald M, Razet D (1997) Effects of high natural seston concentrations on the feeding, selection and absorption of the oyster Crassostrea gigas (Thunberg). J Exp Mar Biol Ecol 212:149-172

Bayne BL, Hawkins AJS, Navarro E (1987) Feeding and digestion by the mussel Mytilus edulis L. (Bivalvia: Mollusca) in mixtures of silt and algal cells at low concentrations. J Exp Mar Biol Ecol 111:1-22

Bayne BL, Iglesias JIP, Hawkins AJS, Navarro E, Heral M, Delous-Paoli JM (1993) Feeding behavior of the mussel Mytilus edulis: responses to variations in quality and organic content of the seston. J Mar Biol Assoc UK 73: 813-829

Bougrier S, Hawkins AJS, Héral M (1997) Preingestive selection of different microalgal mixtures in Crassostrea gigas and Mytilus edulis, analysed by flow cytometry. Aquaculture 150:123-134

Clasing EO, Navarro JM, Lardies MA, Stead RA (1998) Alimentación suspensívora-detritívora en bivalvos de la infauna, una estrategia dual para el aprovechamiento de la oferta alimentaria. Informe final proyecto Fondecyt 19511202. Universidad Austral de Chile Valdivia

Cranford PJ, Emerson CW, Hargrave BT, Milligan TG (1998) In situ feeding and absorption responses of sea scallops Placopecten magellanicus (Gmelin) to storm-induced changes in the quantity and composition of the seston. J Exp Mar Biol Ecol 219:45-70

Falconer RA, Owens PH (1990) Numerical modelling of suspended sediment fluxes in estuarine waters. Estuar Coast Shelf Sci 31:745-762

Fegley SR, MacDonald BA, Jacobsen TR (1992) Short term variation in the quantity and quality of seston available to benthic suspension feeders. Estuar Coast Shelf Sci 34: 393-412

Hawkins AJS, Navarro E, Iglesias JIP (1990) Comparative allometries of gut-passage time, gut content and metabolic faecal loss in Mytilus edulis and Cerastoderma edule. Mar Biol 105:197-204

Hawkins AJS, Smith RFM, Bayne BL, Herald M (1996) Novel observations underlying the fast growth of suspensionfeeding shellfish in turbid environments: Mytilus edulis. Mar Ecol Prog Ser 131:179-190

Hawkins AJS, Bayne BL, Bougrier S, Héral M, Iglesias JIP, Navarro E, Smith RFM, Urrutia MB (1998) Some general relationships in comparing the feeding physiology of suspension-feeding bivalve molluscs. J Exp Mar Biol Ecol 219:87-103

Iglesias JIP, Navarro E, Alvarez PJ, Armentia Y (1992) Feeding, particle selection and absorption in cockles Cerastoderma edule (L.) exposed to variable conditions of food 
concentration and quality. J Exp Mar Biol Ecol 162: $177-198$

Iglesias JIP, Urrutia MB, Navarro E, Ibarrola L (1998) Measuring feeding and absorption in suspension-feeding bivalves: an appraisal of the biodeposition method. J Exp Mar Biol Ecol 219:71-86

Kiørboe T, Møhlenberg F (1981) Feeding, particle selection in suspension-feeding bivalves. Mar Ecol Prog Ser 5: 291-296

Kiørboe T, Møhlenberg F, Nøhr O (1980) Feeding, particle selection and carbon absorption in Mytilus edulis in different mixtures of algae and resuspended bottom material. Ophelia 19:193-205

Labarta U, Fernández-Reiriz MJ, Navarro JM, Velasco LA (2002) Enzymatic digestive activity in epifaunal (Mytilus chilensis) and infaunal (Mulinia edulis) bivalves in response to changes in food regimes in a natural environment. Mar Biol 140:669-676

Navarro E, Iglesias JIP, Pérez-Camacho A, Labarta U (1996) The effect of diets of phytoplankton and suspended bottom material on feeding and absorption of raft mussels (Mytilus galloprovincialis Lmk). J Exp Mar Biol Ecol 198: 175-189

Navarro JM, Thompson RJ (1996) Physiological energetics of the horse mussel Modiolus modiolus in a cold ocean environment. Mar Ecol Prog Ser 138:135-148

Navarro JM, Velasco LA (2003) Comparison of two methods and units of measuring filtration rate in filter bivalves. J Mar Biol Assoc UK 83:553-558

Navarro JM, Clasing E, Urrutia G, Asencio G, Stead R, Herrera C (1993) Biochemical composition of the suspended particulate matter in a tidal flat of Southern Chile: an evaluation of its nutritive value. Estuar Coast Shelf Sci 37: $59-73$

Riisgård HU (1977) On measurements of the filtration rates of

Editorial responsibility: Otto Kinne (Editor-in-Chief), Oldendorf/Luhe, Germany suspension feeding bivalves in a flow system. Ophelia 16: 167-173

Riisgård HU (2001) On measurement of filtration rates in bivalves - the stony road to reliable data: review and interpretation. Mar Ecol Prog Ser 211:275-291

Riisgård HU, Larsen PS, Nielsen NF (1996) Particle capture in the mussel Mytilus edulis: the role of latero-frontal cirri. Mar Biol 127:259-266

Rojas CF (1984) Dinámica anual del seston en el estuario del Río Queule, IX Región. Rev Biol Mar Valparaíso 20: 139-157

Shumway SE, Cucci TL, Newell RC, Yentsch CM (1985) Particle selection, ingestion and absorption in filter-feeding bivalves. J Exp Mar Biol Ecol 91:77-92

Stenton-Dozey JM, Brown AC (1992) Clearance and retention efficiency of natural suspended particles by the rock-pool bivalve Venerupis corrugatus in relation to tidal availability. Mar Ecol Prog Ser 82:175-186

Urrutia MB, Iglesias JIP, Navarro E, Prou J (1996) Feeding and absorption in Cerastoderma edule under environmental conditions in the bay of Marennes-Oleron (W. France). J Mar Biol Assoc UK 76:431-450

Vahl O (1973) Efficiency of particle retention in Chlamys islandica (OF Müller). Astarte 6:21-25

Velasco LA, Navarro JM (2002) Feeding physiology of infaunal (Mulinia edulis) and epifaunal (Mytilus chilensis) bivalves under a wide range of concentration and quality of seston. Mar Ecol Prog Ser 240:143-155

Velasco LA, Navarro JM (2003) Energetic balance of infaunal (Mulinia edulis) and epifaunal (Mytilus chilensis) bivalves in response to wide variations in concentration and quality of seston. J Exp Mar Biol Ecol 296:79-92

Widdows J, Fieth P, Worrall CM (1979) Relationships between seston, available food and feeding activity in the common mussel Mytilus edulis. Mar Biol 50:195-207

Submitted: May 6, 2004; Accepted: December 30, 2004

Proofs received from author(s): March 19, 2005 